\title{
PRIME MINISTERIAL RHETORIC AND RECESSION POLITICS: MEANING MAKING IN ECONOMIC CRISIS MANAGEMENT
}

\section{ADAM MASTERS AND PAUL 'T HART}

Triggered by the collapse of the US mortgage market, the global financial crisis (GFC) of 2007-08 hit most of the Western world hard and fast, presenting governments and citizens with a set of stark, undeniable and immediate realities. This article examines the attempts of three prime ministers "Gordon Brown in the UK, Brian Cowen in Ireland and Kevin Rudd in Australia to meet the key leadership challenge set up by the GFC: to publicly assess, explain and account for the GFC and the accompanying economic turbulence and uncertainty as financial markets went from boom to bust. By focussing on meaning making we examine how the leaders responded to the public expectation to explain: How bad is the situation? How did it occur? Who or what is to be held responsible? What needs to be done to cope with it? Using both qualitative and quantitative methods we compare the rhetorical impacts of these leaders.

\section{ECONOMIC BREAKDOWN AND POLITICAL CRISIS MANAGEMENT}

Triggered by the collapse of the US mortgage market, the global financial crisis (hereafter: GFC) of 2007-08 hit most of the Western world hard and fast. It presented governments and citizens with a set of stark, undeniable, immediate realities. Share markets tumbled, with hundreds of billions of dollars wiped off capital assets day after day. Real estate prices came tumbling down in places such as New York, London and Singapore. Once mighty corporate empires filed for bankruptcy. Others came hat-in-hand to the government to be bailed out or were taken over. The world saw bank runs, Iceland going broke, Wall Street suicides, mass sackings, repossessed homes, abandoned construction sites, and 'negative growth' in most developed economies, and eventually a series of sovereign debt crises in a range of European countries that unleashed huge political and fiscal pressures in the Eurozone.

In this article, we examine how three prime ministers tried to meet one of the key leadership challenges set up by the occurrence of the financial crisis: to publicly assess, explain and account for the highly unpleasant, unexpected, uncertain economic turbulence as financial markets around the world went from boom to bust, and recession seemed to be taking hold. We thus focus on crisis management as meaning-making (through rhetoric and dramaturgy, see 't Hart 1993; Boin, et al. 2005; Hajer and Uitermark 2008) rather than as decision making, deterrence and coordination - the traditional preoccupation of crisis management scholarship (Hermann 1972; Rosenthal et al. 1989). Much like students of 'power' eventually discovered that the discursive framing of issues (Lukes 1974) precedes the role of agenda-setting and allocative decision making in politics at large, recent studies of crisis management have displayed an increasing awareness that the very act of defining and interpreting crises constitutes a crucial battleground for stakeholders in the political and policy struggles that major disruptions elicit. When disruptions occur, Boin et al. (2009) argue, the public expects its leaders to publicly provide quick and persuasive answers to four pivotal questions: (1) How bad is the situation? (2) How did it occur? (3) Who or what is to be held responsible? (4) What needs to be done to cope with it?

Adams Master is a doctoral candidate at the Australian National University. Paul 't Hart is at the Utrecht School of Governance, Utrecht University.

Public Administration Vol. 90, No. 3, 2012 (759-780)

(c) 2012 Blackwell Publishing Ltd, 9600 Garsington Road, Oxford OX4 2DQ, UK and 350 Main Street, Malden,

MA 02148, USA. 
The central puzzle of this article is therefore how three prime ministers whose countries were all affected by the financial crisis tried to frame the unfolding events, and to what extent those framing efforts resonated in the mass media (which we assume are critical in conferring public authority upon leadership efforts) and through poll data.

Prior research (Nacos 1990; Kiewe 1994; Kuypers 1997; Hearit 2006; Boin et al. 2008, 2009) suggests that, contrary to Edelman's (1977) influential assertions, leaders in times of crisis find it no less difficult to authoritatively 'sell' their ways of framing the events and their implications than they do in 'normal' times (see, e.g. Edwards 2003; Hurst 2004). In times of adversity government leaders have to navigate rough political waters. On the one hand, stakeholders and mass publics are watching their every move in a crisis induced longing for strong leadership and authoritative governance: a sense of protection, direction and order (Heifetz 1994; Hajer 2009). On the other, the collective anxiety and outrage that accompanies the occurrence of major disturbances of the public order and prosperity Western societies take for granted, can easily turn itself against the incumbent authorities, who are obvious targets of blame for alleged failures to predict, prevent or adequately prepare for the crisis of the day (Boin et al. 2010).

Meaning making and blame avoidance are therefore part and parcel of the politics of crisis leadership. Operating in an environment of relentless media coverage and a cacophony of voices all trying the shape the public's understanding of the crisis, government leaders need to 'perform authority' (Hajer 2009) in order not to be engulfed by the political firestorms that ensue when they loose control of the crisis narrative. In crises of paramount national importance, the head of government is expected to be the national meaningmaker in chief. If he/she can't or won't perform that role - as did Japanese Prime Minister Kan during the 2011 tsunami/nuclear crisis - there might be a political price to pay.

We will track prime ministerial rhetoric, poll data and media responses to that rhetoric in three countries from the unfolding of the GFC up to mid-2010. We aim to find out how prime ministers described, explained, accounted for and proposed to manage - in other words, framed (Scheufele 1999) - the financial meltdown and its economic consequences as events unfolded. To get a sense of whether their messaging resonated, we examine how the media received their rhetoric (cf. Wood 2007) and track ongoing polling results. We do so to explore whether there are any systemic differences between the nature and impact of the meaning making 'performances' of leaders whose long tenure at the helm of relevant government policy may pressure and constrain them politically in responding to a crisis, and an entirely new prime minister heading a new government with presumably more leeway to 'exploit' the crisis politically as well as in advocating policy change (Boin et al. 2009).

\section{UNDERSTANDING PRIME MINISTERIAL CRISIS RHETORIC: RATIONALE AND DESIGN}

Rhetorical perspectives on political leadership have a long and venerable tradition worldwide. However, the genre of crisis rhetoric as a pivotal area of leadership dramaturgy and political strategizing has been studied intensively in US presidential studies (Bostdorff 1994; Edwards 2003; Whitford and Yates 2009), but hardly at all in parliamentary systems. For example, recent US studies have focused on two domestic crises during the Bush presidency, 9/11 and Hurricane Katrina, in particular the marked differences in response and public reaction (cf. 't Hart et al. 2009; Griffin-Padgett and Allison 2010). This research is supplemented by minute analyses of the rhetorical framing of the war in Iraq (see, e.g. Hutcheson et al. 2004; Hyde 2005; Ben-Porath 2007; Simons 2007; Winkler 2007; Nabers 
2009), and other actions that flowed from the events of $9 / 11$ such as the PATRIOT Act (Domke et al. 2006).

There are limits to the extent to which these presidential studies can be transplanted to the Westminster context. First, presidents often have no long 'history' within executive government and find it much easier to distance themselves from past policies that become targets for criticism during a crisis than prime ministers who often have had long ministerial careers before acceding to the top job. Furthermore, prime ministerial office carries a greater obligation to the party system than the office of president. Prime ministers are technically dependent on the support of their parliamentary colleagues to retain their leadership. Although in recent years some argue this dynamic has changed in the era of alleged 'presidentialization' of prime ministerial office, or where a much smaller group formulate policy and crisis response with the prime minister, and power has accreted around the office itself (Foley 2001; Poguntke and Webb 2005; Walter and Strangio 2007; Rawnsley 2010; Taylor and Uren 2010). Although this appears to be the trend, it is inconceivable that a US, French or Russian president could be removed from office by party powerbrokers in the way Australia's prime minister was unceremoniously dumped in mid-2010 (cf. Cassidy 2010), or indeed Margaret Thatcher was ousted by her party in 1990.

As a result of these two factors, one could argue that in times of crises prime ministers feel the dilemma of 'making meaning authoritatively whilst managing blame' even more acutely than presidents tend to (in presidential systems like France and Russia presidents tend to manage crisis-induced blame by hectoring or firing ministers and even prime ministers). We should therefore study more urgently how they cope with this dilemma.

Ours is an explorative study of prime ministerial rhetoric of which, in comparison to presidential rhetoric, we know comparatively little. This is not to say that no prior work of this kind has been done (Reicher and Hopkins 1996; Gaffney 2001; Seymour-Ure 2003; Curran 2004; DeCastella et al. 2009), but that we are only beginning to explore the full implications of the emerging 'rhetorical premiership' (Helms 2008; Toye 2010). More recently, Christopher Hood and colleagues' work on blame management as a 'staged retreat' has begun to fill some of this void (Hood et al. 2009). The present study continues this momentum by offering an alternative analytical framework that incorporates but goes beyond blame management and views crisis rhetoric in the broader context of the politics of crisis 'exploitation' as explored by Boin et al. (2009) - an approach that unlike Hood et al.'s allows for offensive as well as defensive strategic aims and semantic postures by government leaders. Our approach is also inspired by recent developments in the field of business and political communication, where Griffin-Padgett and Allison's (2010) study of restorative rhetoric and Hearit's (2006) analysis of 'crisis management by apology' have opened new ground to explore the 'strategic communication that helps to alleviate risk and restore public safety with a deeper, more humanistic communication' (Griffin-Padgett and Allison 2010, p. 377).

Moreover, though we are not the first to study the economic rhetoric of leaders (Kuypers 1997; Bligh and Hess 2007; Wood 2007) per se, our focus on the subgenre of crisis rhetoric has seldom been applied to economic instead of national security contingencies (Bostdorff 1994; Kiewe 1994; Kuypers 1997). This is a significant omission. Like security threats, dramatic episodes in the economic life of a polity such as financial crises and major recessions can cast long shadows on the polities in which they occur. The sense of threat and uncertainty they induce can profoundly impact people's understanding of the world around them, and de-legitimize existing institutional arrangements and authority relationships ('t Hart 1993) by 'dislocating' hitherto dominant social, political 
or administrative discourses (Wagner-Pacifici 1986; Hajer 2009). Apportioning blame and advocating reform are therefore integral parts of the 'framing contests' that crises elicit (Hearit 2006; Boin et al. 2009).

The third contribution is an advantage presented by the GFC itself. Previous research has compared how the leadership of one or more incumbents of a particular office deal with singular or multiple crises. In this study we are looking at how multiple holders of the same office deal with what is essentially the same transnational crisis, often playing out at the same time in 'real-time' (rather than government-specific 'political time', see Skowronek 2008). This allows for a more salient cross-leader comparison.

A caveat is in order here. We certainly do not claim that the nature and public reception of their crisis rhetoric decisively shaped national crisis responses or indeed the political fate of these leaders (each of the three leaders studied here lost office shortly after the events covered here). We do believe that by closely studying prime ministers' meaningmaking 'performances' in times of crisis we advance both the study of crisis management and the comparative understanding of executive leadership in parliamentary systems.

To examine our central question, we perform a primarily descriptive, but theoretically informed comparative study design. We pragmatically combined elements of most-similar and most-different logics of small-n comparative analysis (George and Bennett 2004). We selected three countries with similar attributes: rich, Western, Westminster, and each led by a prime minister who had only served a short time in the roles as the crisis broke - Gordon Brown (UK), Brian Cowen (Ireland) and Kevin Rudd (Australia). Elements of difference we leveraged to articulate a number of exploratory hypotheses included: ideological position (Brown and Rudd from centre-left labour parties; Cowen from the centrist Fianna Fáil party); economic impact (UK and Ireland hit fast and deep, Australia late and shallow); and political opportunity structure (Brown and Cowen had been longserving finance ministers before becoming prime minister, each in politically awkward circumstances (cf. O’Malley 2008, 2009; Rawnsley 2010); Rudd in contrast became prime minister after the November 2007 election that brought his Labour party back in power after 11 years of opposition).

Analytically, we followed Boin et al.'s (2009) crisis exploitation framework, which posits that where actors 'stand' with respect to answering the four key crisis framing questions presented above, depends on where they 'sit' (in terms of role and ideology) as a crisis unfolds; and that the success of actors' framing attempts largely depends upon their ability to present themselves as 'squeaky clean' when it comes to causing or aggravating the crisis in the first place.

Therefore, based upon (a) their longevity of tenure prior to the breaking of the GFC, and (b) their ideological posture on the classic left-right continuum, we loosely expect the following patterns of crisis rhetoric for the leaders in question:

(1) On severity: Rudd to be most inclined to talk up the crisis, and Brown and Cowen to talk it down (at least initially).

(2) On causality / responsibility: Rudd more inclined than Brown and Cowen to attribute the crisis to endogenous factors and thus focus blame identifiable actors rather than systemic factors.

(3) On policy: Cowen to be the least and Rudd the most inclined to argue the case for a macro-economic policy switch towards Keynesian style stimulus and interventionist regulatory responses. 
(4) On impact: Rudd to be more likely than Brown and Cowen to be able to obtain public support for his stances.

Second, our design mixes elements from both the qualitative and quantitative traditions within political communications research (Graber 2004). To analyse leaders' framing efforts we used a qualitative approach. From the database of speeches on each PM's website we selected speeches in which the prime minister substantively covered the GFC. These totalled 51 speech acts by Gordon Brown, 39 by Brian Cowen and 78 by Kevin Rudd. The method of delivery also varied, from podcasts by Brown through to a lengthy essay by Rudd. These were coded for the number of times the leader used crisis rhetoric in each speech, whether they mentioned the oppositions policies, and whether the opposition's position at the time was substantively supportive of the government and its policies or opposed to it. We will present our findings in terms of both quantitative tables and qualitative examples of crisis rhetoric used by each leader to illustrate the type of language they employed to frame the unfolding crisis.

In addition we content analysed media coverage response in terms of the extent of expressed support for the key components of leaders' crisis frames (severity, causality, policy implications) as well as for the leaders themselves. We also juxtaposed this with polling data to obtain another measure of how prime ministerial crisis leadership performance resonated publicly.

In what follows we first describe the political context each prime minister faced as the GFC unfolded. We then compare their crisis rhetoric. Next we review media and public reactions to each leader's meaning-making efforts. We conclude by examining our findings in terms of the analytical framework presented above and offering some thoughts on this study's implications.

\section{THREE PRIME MINISTERS AND THE GLOBAL MELTDOWN}

\section{Gordon Brown}

The boom years that accompanied the first decade of the first three-term Labour government (1997-2010) were hailed by Gordon Brown, then Chancellor of the Exchequer, as a 'Golden Age', thanks to the finance and banking sector, just months before the edifice came crashing down (Rawnsley 2010, p. 476). As Chancellor, Brown had eased regulation and taxes, transferring responsibility for the financial sector from the Bank of England to a new Financial Services Authority (FSA). This created a tripartite regime between the Bank, FSA and Treasury (Rawnsley 2010, pp. 482-4) which fundamentally changed the foundations of UK financial regulations.

Gordon Brown became Prime Minister in June 2007 after a long and toxic relationship with his predecessor (cf. Rawnsley 2010). Early in his premiership, Brown received several boosts to his popularity from his leadership during various crises. Within days of taking office, two major terrorist attacks were thwarted, and a third on Glasgow airport resulted in a single casualty, the suicide bomber. A breakout of foot-and-mouth disease similarly reinforced the image of Brown as the man-in-charge. Even the first manifestation of the GFC, the run on the Northern Rock bank, paradoxically boosted Brown in the polls. This could be interpreted as voters looking to Brown for security, as the uncertainty in the finance sector grew (Rawnsley 2010, pp. 476-95). These events helped place Labour ahead of the Conservatives, who they had trailed in the last days of Tony Blair's government (the momentary lead in the polls even led to speculation that Brown would call an early election). 
We have analysed six meaning-making occasions used by Brown: (1) the nationalization of the Northern Rock bank on 18 February 2008 following the first run on a UK bank in over a century; (2) the October 2008 speech that followed the bank guarantees; (3) Brown's April press conference following the London summit he hosted as president of the G20 proclaiming the end of the Washington consensus of neo-liberal market dominance; (4) the speech delivered to the last 'New Labour' conference in September; (5) the impromptu address to G20 finance ministers in November where Brown reinforced previous themes of integrity and values for global markets; and (6) the attempt in March 2010, when in full election mode, to frame his handling of the GFC as illustrative of his abilities as an economic manager (Brown 2008a, 2008g, 2009h, 2009m, 2009r, 2010e).

\section{Brian Cowen}

Ireland's small, open economy and membership of the EU and Eurozone shaped her experience of the GFC. The 'Celtic Tiger' years had built Ireland's economic success through foreign investment and high-tech industry, and set the domestic finance and real-estate markets booming. The high tax revenues resulted in major expansion of public sector and welfare spending. Although not highly exposed to the US sub-prime mortgage market, Irish banks had lent heavily to property developers, creating a bubble that burst. Lending stopped, house prices crashed, unemployment spiked and the economy spiralled downwards (Masters 2009).

Cowen became Taoiseach (prime minister) after Bertie Ahern, the Taoiseach since 1997, stood aside. Ahern had won the May 2007 general election, but was embroiled in a corruption inquiry involving payments by developers to politicians and planning officials (O'Malley 2009). Cowen's accession followed four years as Ahern's Minister for Finance, presiding over the then booming economy. As Taoiseach, Cowen led a minority government dependent on support from the Greens and Progressive Democrats.

Seven key points during the GFC in Ireland have been identified. A speech by Cowen at each point has been subjected to media analysis in Section 5.2 below. Chronologically these were: the October 2008 guarantee for bank deposits; January 2009's crisis plan, A Framework for Sustainable Economic Renewal; the subsequent rift with the unions from the Social Partnership four days later; the creation of a National Assets Management Agency (NAMA) to clean up toxic debts held by Irish banks announced in the April supplementary budget; Cowen's attempt in July to justify his actions when he was Finance Minister using IMF and OECD reports; the tough budget of December; and finally Cowen's May 2010 'mea half-culpa' where he acknowledged some of the blame for the mess in Ireland's economy (Cowen 2008d, 2009c, 2009e, 20091, 2009m, 2009x, 2010f).

\section{Kevin Rudd}

Australia entered the GFC with economic and public policy positions that would become the envy of the developed world. Its financial regulation regime had been overhauled following the Asian crisis of the 1990s and the collapse of a domestic financial giant in the early 2000s. Its economy was booming on the back of spiralling Asian demand for resources. The state was debt-free and had been running budget surpluses for years.

Unlike his British and Irish counterparts, Australian Labour leader Kevin Rudd was genuinely a new head of government, having won the October 2007 election that ended 11 years of conservative government. Unlike Cowen and Brown, Rudd could not be held accountable for any short-term damage the GFC might inflict. On the contrary, should the crisis hit Australia, it could serve as a political weapon with which he could strike his predecessors. 
Our analysis of Rudd's meaning-making focuses on: (1) his acknowledgement of the crisis in March 2008; (2) the address to the nation on 14 October, explaining the bank guarantees and announcing a AU\$10.4 billion stimulus package; (3) his announcement of a 'temporary budget deficit', the first in years; (4) Rudd's February 2009 essay blaming neo-liberalism for the GFC; (5) a 'stump' speech presented in multiple venues between April and May 2009, preparing the country for deficit created by the government's stimulus package; (6) Rudd's June pitch to the Australian Council of Trade Unions (ACTU), a core constituency for Labour, while his Deputy Julia Gillard was confronting the unions over workplace reform; and (7) a Berlin G20 press conference in July, where Rudd continued to warn that despite comparatively benign economic data, Australia was 'not out of the woods yet' (Rudd 2008e, 2008r, 2008z, 2009a, 2009j, 2009s, 2009z).

\section{NAMING AND FRAMING THE FINANCIAL CRISIS}

From the July 2007 collapse of Bear Sterns in the United States, the prime ministers were slow to engage crisis rhetoric in response to what was seen as fundamentally a US problem. In January 2008, Rudd acknowledged that 'over the last six months the global economy had entered uncertain times' (Rudd 2008a). The following month, Brown similarly acknowledged ' 6 months of financial turbulence', when he announced the bailout of the Northern Rock bank (Brown 2008a). Cowen, who took office in May 2008, spoke of the threat to the Irish economy from 'the effects of financial market turbulence' in a speech to business leaders in late June (Cowen 2008a). These speeches have been taken as a starting point for the data in table 1. The end point is June 2010, when Brown had been defeated electorally, Rudd had been ousted by his party, and Cowen was politically doomed by an economy spiralling out of control.

\section{Severity: how to call a spade a spade}

Characterizing the national impact of the global financial instability was the first meaning-making challenge for each prime minister. All used meteorological analogies.

TABLE 1 Public communication about the GFC - use of crisis rhetoric as \% of the number of speeches

\begin{tabular}{|c|c|c|c|}
\hline Themes used & $\begin{array}{l}\text { Brown } \\
(\mathrm{N}=51)\end{array}$ & $\begin{array}{l}\text { Cowen } \\
(\mathrm{N}=39)\end{array}$ & $\begin{array}{l}\text { Rudd } \\
(\mathrm{N}=78)\end{array}$ \\
\hline \multicolumn{4}{|l|}{ Severity } \\
\hline Weather analogy & $19.6 \%$ & $46.2 \%$ & $47.4 \%$ \\
\hline Worst crisis since... & $17.6 \%$ & $35.9 \%$ & $57.7 \%$ \\
\hline Unprecedented & $15.7 \%$ & $28.2 \%$ & $9.0 \%$ \\
\hline Recession & $43.1 \%$ & $48.7 \%$ & $60.3 \%$ \\
\hline Strength in domestic economy & $17.6 \%$ & $7.7 \%$ & $53.8 \%$ \\
\hline Comparison to other nations' fortunes & $19.6 \%$ & $25.6 \%$ & $59.0 \%$ \\
\hline \multicolumn{4}{|l|}{ Causality } \\
\hline A global problem & $52.9 \%$ & $51.3 \%$ & $60.3 \%$ \\
\hline Blames greed or banks & $35.3 \%$ & $15.4 \%$ & $21.8 \%$ \\
\hline Blames opposition & $3.9 \%$ & $0.0 \%$ & $15.4 \%$ \\
\hline Opposition frame/position & $17.6 \%$ & $20.5 \%$ & $26.9 \%$ \\
\hline \multicolumn{4}{|l|}{ Policy response } \\
\hline Bank guarantees/stimulus & $68.6 \%$ & $66.7 \%$ & $82.1 \%$ \\
\hline Defence of guarantees/stimulus & $54.9 \%$ & $38.5 \%$ & $59.0 \%$ \\
\hline Helping families and businesses & $78.4 \%$ & $10.3 \%$ & $56.4 \%$ \\
\hline
\end{tabular}


However, Cowen's oft used 'economic turbulence' and 'storm' do not convey the same sense of severity as Brown's 'economic Hurricane' (Brown 2009b) or Rudd's economic 'cyclone', 'maelstrom' and 'tsunami' (Rudd 2008s, 2010c, 2010e). Rudd clearly felt able to talk up the severity of the GFC in the nation least affected by the crisis. Another example was Rudd's free use of the word 'recession', which was higher than the total number of Cowen's GFC speeches, but which he used surgically to denote how the GFC affected other countries, or the fact that Australia had avoided a protracted downturn.

The magnitude of what was occurring also required a historical frame. For Brown the chief analogy varied from the 1990s' Asian financial crisis, through the Great Depression of the 1930s to a global crisis 'of a speed and scope and scale quite unprecedented in history' (Brown 2009g). Cowen gave local context starting with the Irish economy in the 1980s, through the Depression to the 'biggest challenge to [Ireland's] economic independence it has ever had to face' (Cowen 2009x). Rudd started off with characterizing the crisis as 'the worst global economic conditions in almost twenty years' (Rudd 2008g), which then became the 'worst financial crisis in our lifetime' (Rudd 2008r), and eventually a 'global financial crisis of a magnitude not seen since the great depression' in which 'unprecedented times called for unprecedented measures' (Rudd 2008v). Rudd's severity rhetoric was eventually scaled down as Australia avoided recession.

\section{Causality: 'not invented here'}

Each prime minister tried to emphasize the role of exogenous factors in causing the crisis. In terms of domestic audiences, this was not such a difficult sell. By presenting a problem that 'started in America' (Brown 2008e), 'rooted in the excesses of the United States money system' (Cowen 2008c) and was 'spreading now to the real economy' (Rudd $2008 \mathrm{u}$ ), the prime ministers provided citizens with simple and politically 'safe' causal interpretations. The emphasis on 'global' confined the game to an international space where the opposition could not effectively compete (cf. Boin, et al. 2009, pp. 90-1).

Rudd subsequently furnished a more ideological and at least partly 'domesticated' interpretation of the crisis. In a long essay (Rudd 2009a) he no longer simply blamed greedy irresponsible US risk-takers but also a flawed system, underpinned by a discredited ideology and the lax regulation that had sprung from it (and which the other side of politics had aided and abetted for the past 11 years). The crisis 'called into question the prevailing neo-liberal economic orthodoxy of the past 30 years' which had 'not served Australia well in preparing for the current crisis'. Though recognizing 'the great strengths of open, competitive markets', Rudd's ideological antidote was 'social democracy', which had to 'save capitalism from itself' (Rudd 2009a).

Brown was notably the most strident of the three in blaming banks and greed. As a global financial hub, the government bailed out and guaranteed the city; leaving the UK government more greatly exposed than either Australia or Ireland. Hence perhaps Brown's move to criticize bonuses and payouts for senior bankers. Following a meeting of G20 leaders in London in April 2009, Brown found an ally in Rudd in spreading this message, during a forum on the moral questions raised by the GFC (Brown 2010j, pp. 66-70).

Their long prior tenure as finance ministers was a sore point for both Brown and Cowen that they somehow had to address. Cowen, for example, argued that his (precrisis) decisions as Finance Minister had always been based on IMF and OECD growth predictions. He also claimed that low interest rates set by the European Central Bank fuelled the Irish housing boom. And he targeted the opposition and some media who had called for greater deregulation in 2005/06, which Cowen had then resisted (Cowen 2009m). 
Cowen's address to business leaders in May 2010 took place against the backdrop of three looming by-elections. As a minority government, the results had the potential to alter the balance of power in the Dáil. Cowen needed to frame his role as favourably as possible to the public before an imminent inquiry into the financial malaise would kick in. He claimed Ireland would have had a 'soft landing' from its own banking crisis had the GFC not impacted. The light touch the government had had on the economy pre-GFC had, according to Cowen, been based on advice from the IMF, OECD, EU and other bodies. In his speech the Taoiseach quoted extensively from their reports. To further his no-fault claim, Cowen talked up all the financial measures he had taken, claiming that 'without these actions the crisis in the Irish economy would have been far worse'.

Sensing that continued total denial of responsibility would be politically unsustainable, Cowen resorted to what was neatly described as a 'mea-half-culpa'. In an analysis of eight critical factors, he acknowledged the 'inadequacy of financial regulatory controls' and that property tax incentives had been maintained for too long. He also mentioned a 'failure to implement more intensive compliance regulation'. The five other factors remained squarely exogenous. Still, this was a key shift to at least partial blame acceptance by Cowen for his government's contribution to the financial crisis.

\section{Policy: 'saving' the economy}

All three prime ministers found it necessary to both explain and justify the bank guarantees as well as the other drastic crisis measures their governments were taking at the time. Of the three, Kevin Rudd spoke most offensively, focusing on his government's stimulus effort and how it was 'designed to cushion the impact of the global economic recession on Australia' (Rudd 2009d). When Australia was spared even a technical recession, talking up the stimulus remained a fixture in his talks as Rudd attempted to reap the success of his government's response to the GFC. Cowen was the most subdued of the three when it came to policy discourse, defending the guarantees and stimulus less often than the others. This was probably because the stimulus did not stem the economic tide and the banking guarantee led to spiralling commitments by the Irish government in an attempt to save its financial sector.

There were interesting differences in emphasis when it came to characterizing the chief aims and recipients of their policies. Gordon Brown rarely let an opportunity pass to reinforce his government's determination 'to take all the far reaching decisions needed to support British families and British businesses through these difficult times' (Brown 2008h). Kevin Rudd spoke of supporting families and business in the context of the GFC as often as not. However, Brian Cowen's language rarely used the term 'families', referring instead to the need to return people to work to help the economy and support mortgage holders (and in turn the ailing banks).

\section{RHETORIC THAT RESONATED?}

In this section we use media and polling data to track public opinion reception of the key speeches we briefly outlined above. Tables 3 to 5 chart the extent of agreement with prime ministerial framing of the severity, causes and policy implications of the GFC. Opinion poll data in table 2 is taken from the first poll conducted after each speech.

\section{Brown's unrewarded 'statesmanship'}

The media sources for Brown are The Guardian/Observer, The Times, and the Financial Times. Opinion poll data relating to Brown's approval ratings in the week following each speech is from YouGov (2008a, 2008b, 2009a, 2009b, 2009c, 2010). 
TABLE 2 Polling trends

\begin{tabular}{|c|c|c|c|c|c|c|}
\hline & \multicolumn{2}{|c|}{ Brown } & \multicolumn{2}{|c|}{ Cowen } & \multicolumn{2}{|c|}{ Rudd } \\
\hline & Poll & Speech & Poll & Speech & Poll & Speech \\
\hline Sep 2008 & $16 \%$ & & $36 \%$ & & $50 \%$ & \\
\hline Oct 2008 & $27 \%$ & Unprecedented times & $26 \%$ & Bank guarantee & $65 \%$ & National address \\
\hline Nov 2008 & $31 \%$ & & $30 \%$ & & $67 \%$ & Temporary deficit \\
\hline Dec 2008 & $29 \%$ & & $29 \%$ & & $70 \%$ & \\
\hline Jan 2009 & $27 \%$ & & $28 \%$ & Crisis plan & $63 \%$ & \\
\hline Feb 2009 & $25 \%$ & & $23 \%$ & $\begin{array}{l}\text { Break with social } \\
\text { partners }\end{array}$ & $66 \%$ & Monthly essay \\
\hline Mar 2009 & $24 \%$ & & $28 \%$ & & $63 \%$ & \\
\hline Apr 2009 & $22 \%$ & G20 leaders & $23 \%$ & Supplementary budget & $66 \%$ & $\begin{array}{l}\text { We're all in this } \\
\text { together }\end{array}$ \\
\hline May 2009 & $17 \%$ & & $24 \%$ & & $56 \%$ & \\
\hline Jun 2009 & $18 \%$ & & $24 \%$ & & $58 \%$ & ACTU conference \\
\hline Jul 2009 & $19 \%$ & & $24 \%$ & IMF/OECD reports & $63 \%$ & G20 role \\
\hline Aug 2009 & $19 \%$ & & $24 \%$ & & $61 \%$ & \\
\hline Sep 2009 & $20 \%$ & Labour conference & $24 \%$ & & $67 \%$ & \\
\hline Oct 2009 & $20 \%$ & & $25 \%$ & & $59 \%$ & \\
\hline Nov 2009 & $22 \%$ & G20 Finance ministers & $23 \%$ & & $56 \%$ & \\
\hline Dec 2009 & $22 \%$ & & $25 \%$ & Annual budget & $58 \%$ & \\
\hline Jan 2010 & $23 \%$ & & $27 \%$ & & $50 \%$ & \\
\hline Feb 2010 & $29 \%$ & & $27 \%$ & & $51 \%$ & \\
\hline Mar 2010 & $34 \%$ & Protecting the recovery & $24 \%$ & & $51 \%$ & \\
\hline Apr 2010 & $35 \%$ & & $23 \%$ & & $39 \%$ & \\
\hline May 2010 & $35 \%$ & & $24 \%$ & Mea-half-culpa & $36 \%$ & \\
\hline Jun 2010 & $35 \%$ & & $24 \%$ & & $36 \%$ & \\
\hline
\end{tabular}

Notes on poll sources:

1. YouGov (UK). Question: Are you satisfied or dissatisfied with Gordon Brown as Prime Minister? Figures for May/Jun 2010 reflect the election result.

2. RedC (Ireland). Question: If there were a General Election tomorrow, which party or independent candidate do you think you would give your first preference vote? Percentages are for Fianna Fáil.

3. NewsPoll (Australia). Question: Are you satisfied or dissatisfied with the way [Kevin Rudd] is doing his job as prime minister?

4. Some caveats: Bold percentages are averages where quoted polls are not available; data for the period following Rudd's and Brown's first speeches were excluded; Ireland's multiparty system partially explains Cowen's comparatively low overall ratings (as support is dispersed across more parties).

In all instances, there was greater agreement than disagreement with Brown's severity narrative. At the time of Northern Rock's nationalization, a couple of commentators disagreed with Brown's narrative. Christine Seib in The Times could not accept an assertion by Brown that the reputation of the London market had not been damaged (Seib 2008). Peter Riddell, wrongly, predicted that the UK was not heading for a financial crisis, but 'a difficult year or two... .with slow growth. . .and temporarily higher inflation' (Riddell 2008). As the crisis wore on, there was less commentary on severity. The minor spike before the general election reflected a response to Brown's renewed rhetoric on the GFC as he tried to exploit it politically.

Brown was unable to excite interest, let alone support for his causal frame. None of the speeches analysed resulted in more than 45 per cent commentary, and only three barely broke 30 per cent in terms of support. Unlike Cowen, who presided over a 'small open economy', Brown's 'open economy' was significantly larger. In this context, Britain's financial market was as much an influence on the global factors as it was influenced by the GFC. 


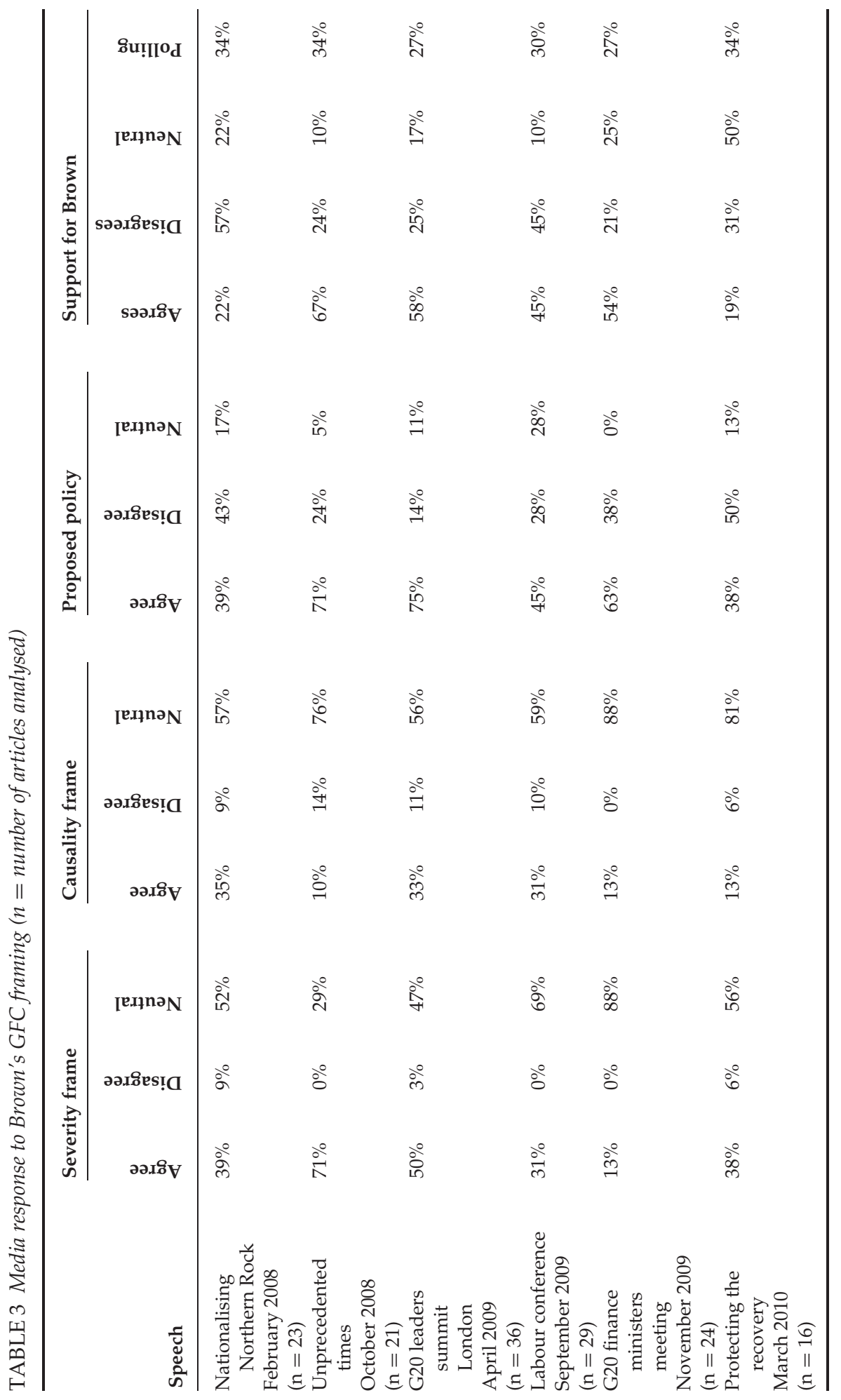


Between October 2008 and the end of 2009, Brown enjoyed greater media support for the global policies he espoused: coordinated slashing of central bank rates; cutting bonuses for bankers who were blamed for the excesses that led to the crash, which proved popular with the party; and targeting tax havens in his impromptu address to G20 finance ministers. Despite this, the media never forgot Brown's legacy as Chancellor, which they argued had created the conditions for a deeper slump in Britain than many other advanced nations.

In the week immediately following each speech the recorded media support for Brown's overall leadership was relatively strong. On the three occasions it peaked over 50 per cent. Key factors were in play each time. In October 2008, the global financial system teetered on collapse. It was only the massive injections of capital and banking guarantees by major economies, led in great part by Brown, that prevented total collapse. Brown also clearly benefited from his presidency of the G20. Public perception of Brown being the man-of-the-hour, combined with populist rhetoric of regulation and reining in bonuses played well. This did not, however, translate into a significant uplift in the opinion polls (see table 2). On the contrary: some of the early spikes in support he enjoyed after replacing Blair, Brown's GFC rhetoric and 'statesmanship' were not enough to offset the tidal wave of anti-Labour feeling that was sweeping the country (Rawnsley 2010). Brown simply could not escape his own legacy.

\section{Cowen's growing credibility gap}

The media sources for Cowen are the Irish Times, Irish Independent and Sunday Business Post. Public opinion data here pertain to support for Cowan's Fianna Fail party, taken from REDC (2010).

In most instances, media reports in the week following each speech reflected general agreement with Cowen's severity frame. In two instances only, the April budget speech and the Taoiseach's response to IMF and OECD reports, was there disagreement on the severity. Commentary on the April budget reflected belief that the situation was worse than that presented by Cowen, whereas commentators reframed the situation at the time of the IMF and OECD reports as less severe, being 'an unwelcome '80s revival - bad, but not quite unprecedented' (Irish Independent 2009). By the time of the December budget and Cowen's attempted mea culpa, total commentary fell to less than 40 per cent, possibly reflective of a media and public fully aware of how hard Ireland had been hit by the GFC.

Cowen's attempts to externalize the causality of the GFC met with initial success; however this fell away as more detail on the extent of mismanagement in the domestic property and finance sectors emerged. The public generally accepted the narrative concerning poor behaviour in banks locally and internationally. However, on both occasions when Cowen attempted a new frame where the banks, property developers and international markets were still the number one cause, but his government should be absolved, the negative response sunk to new depths. Some of the most scornful articles resulted, describing Cowen's excuses as juvenile and a Bart Simpson or 'the big boy did it' defence (Lydon 2010).

The deposit guarantee was the sole occasion Cowen gained significant policy support in the press. Support fell as the situation deteriorated and tougher measures were required. The attempts to push public service reform met stiff criticisms; particularly attempts at pension reform, which sparked a backbench revolt. Similarly the cuts in both budgets were unpopular in at least half the commentary, and failed to draw support from more than a fifth of the press reports. 


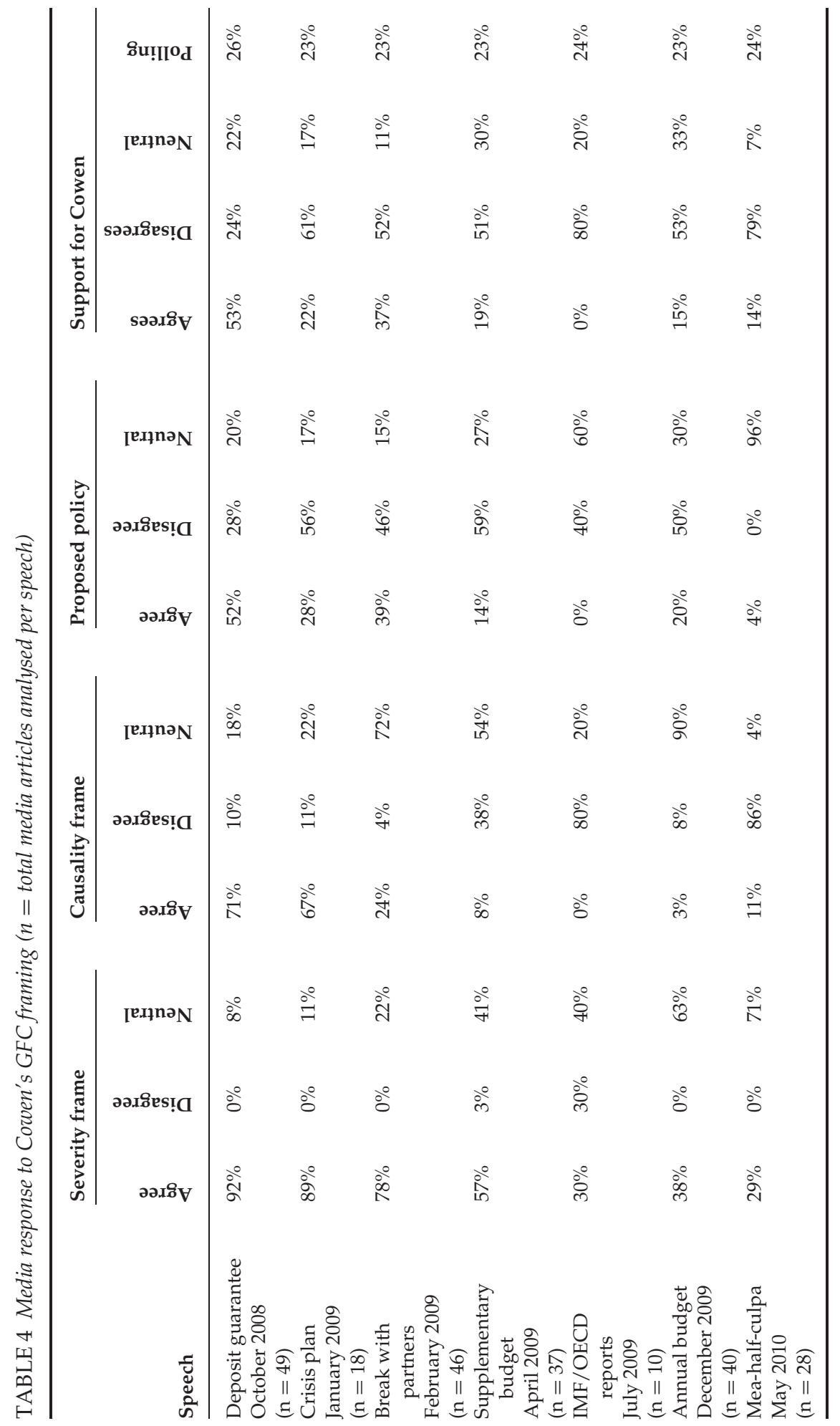


Cowen was in the same boat as Brown, only worse so. He was unable to gain significant support in the press and in the polls (see table 2) following the banking guarantee and this had much to do with his history as Finance Minister. Even the banking guarantee was strongly criticized in the letters to the editor of the Irish Times, questioning the fiscal and economic policies from that time. Negative response to Cowen mostly exceeded 50 per cent in the articles analysed, peaking near or at 80 per cent disapproval for the public service reforms and his attempts to defend his past record. Cowen achieved a small spike of media approval, attributed to a perception of a stronger leader, when the Social Partnership began to break down. Yet the polling data (table 2) indicates that the Irish public remained steadfast in what amounted to a firm rejection of an unelected prime minister whose economic authority was severely compromised by his ministerial past.

\section{Rudd's crisis exploitation attempt}

Table 5 charts the support for Rudd and Labour policies expressed in The Australian, The Age and the Australian Financial Review, and Rudd's preferred PM status from Newspoll.

Early into the GFC, the overwhelming media response to Rudd's severity frame was either accepting or neutral. Reports of systemic failure overseas supported these initial responses. However, later speech acts often coincided with economic data that was not as severe for Australia as that experienced by other nations. This led to questioning of exactly how bad Australia's position was, particularly as Rudd's later speeches opened with a frame of dire global crisis, and concluded with details of how Australia had 'weathered the global economic crisis better than most' (Rudd 2009z).

Commentary on Rudd's causality frame was often muted. In March 2008, the global credit crunch was biting, but had not yet developed into the GFC, and by the time of banking guarantees and the move to deficit, commentary accepted the blame placed on global markets, or was otherwise neutral. However, Rudd's essay drew sharp criticism when he tried to frame the causes in terms of failed neo-liberal ideology. Subsequent attempts at a causal frame were largely ignored by the media, which preferred to reflect on the essay's causal claims rather than Rudd's contemporary utterances.

As Labour policies to counter the GFC were rolled out, the majority of commentary was supportive, or at least silent in respect to the stimulus spending. Again Rudd's essay proved a pivotal point in debate. Those who disagreed with his new causal narrative took the opportunity to question the size and choices related to deficit spending. When the narrative moved back to the safer ground of job creation and protection, media support returned.

Media support for Rudd was at a low ebb during the months when the economic outlook in Australia was dim. His controversial essay did not help him either. But the apparent success of the first stimulus package in stemming the economic tide (which became clear during the second quarter of June 2009) lifted his reputation as an astute economic manager. Throughout all of this, Rudd continued to enjoy one of the most remarkable honeymoons with the Australian public (see table 2). Even putting the country back into debt did not bring his approval ratings down from the stellar heights of more than 60 per cent; the Australian people clearly accepted the rationale for the government's actions that their prime minister offered. (Just six months later, it was all over: Rudd's political capital evaporated - see the drop in his ratings in table 2 in early 2010 - after a major U-turn on climate change policy and he was ousted by a party room coup; paradoxically precisely because Australia escaped recession the public came to regard it as a 'non-event', did not 


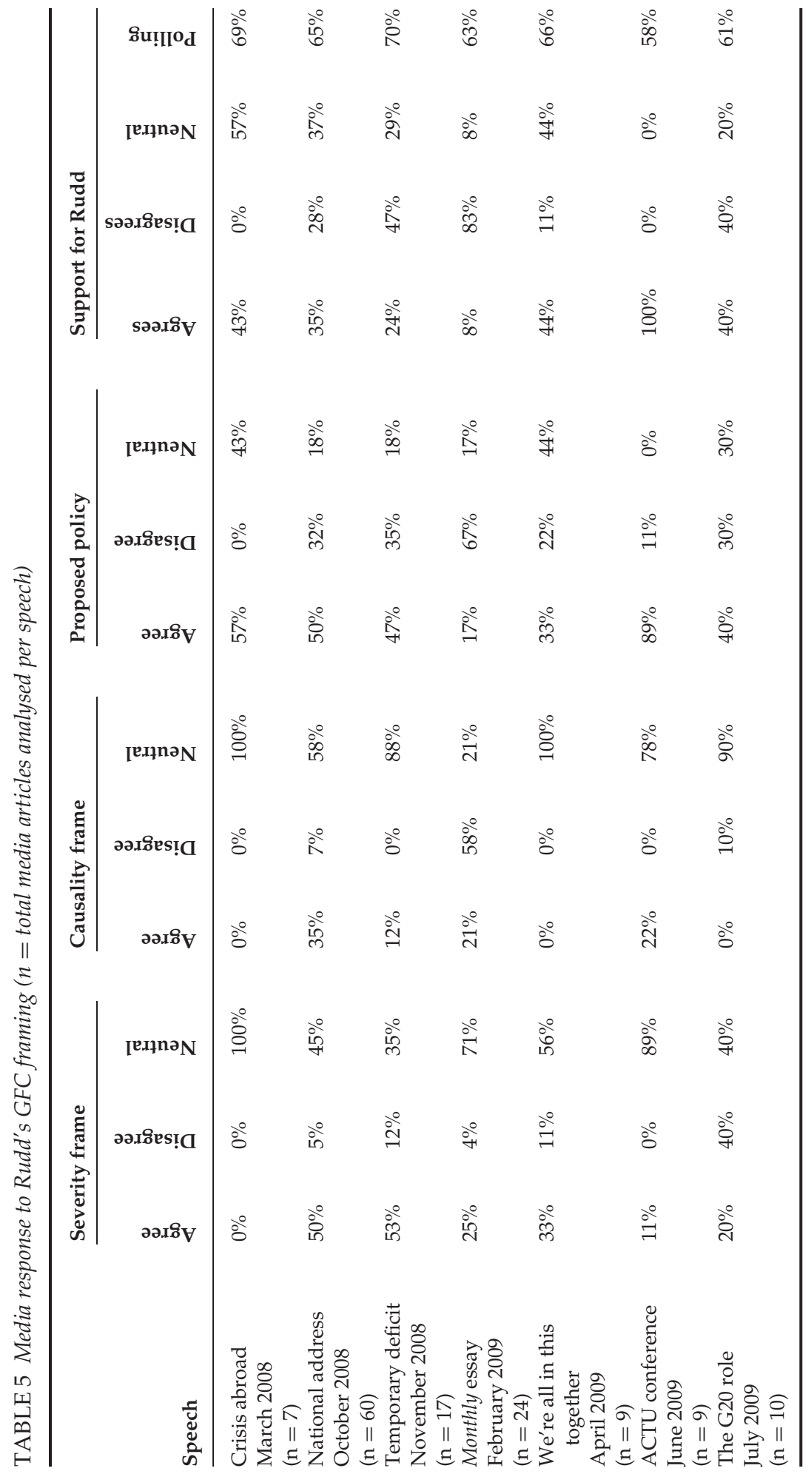


grasp just how much Rudd's government had contributed to achieving that outcome, and consequently no longer gave him political credit for it.)

\section{TALK IS SOFT WHEN REALITIES ARE HARD: THE LIMITS OF RHETORICAL CRISIS MANAGEMENT}

To what extent do these cases conform to the expected pattern of context and situation (rather than personal characteristics) driving the content and reception of prime ministerial crisis framing outlined in Section 2? Combined and compared, the three cases demonstrate moderate to strong support for the expectations formulated at the outset. On severity, once the GFC hit Australian shores, Rudd, unburdened by portfolio responsibilities in the crisis incubation period, engaged in none of the prevarication that marked Brown and Cowen's early speeches, where talking down the problems was in part aimed to allay growing market and public fears about the resilience of UK and Irish financial institutions and in part a first line of defence in the blame avoidance game both were soon forced to play.

On causality/blame, the predicted pattern was not fully confirmed. Brown and Cowen did overwhelmingly attribute the crisis to exogenous factors (both in geographical terms, emphasizing the 'global', and in political terms, emphasizing the role of market as opposed to government actors, and conveniently glossing over any domestic regulatory laxness in 'taming' the alleged 'greed' of those market actors), but contrary to the prediction Rudd initially did too. It took him a good three months to realize that there was political capital and reform momentum for him to be gained out of endogenizing the causal story of the crisis. But when he did, he went out with all guns blazing, advocating a highly ideological reinterpretation of both the causes and implications of the GFC.

On policy our expectation was also largely confirmed. Both Brown and Rudd were, as predicted, more active in advocating changes to the neo-liberal status quo in financial regulation and macro-economic policy. Moreover, where Brown mainly took aim at the institutional quo at the international level (thus avoiding difficult conversations about his own domestic regulatory record), Rudd felt free to combine a highly activist international programme (among others he claimed he was one of the architects of the G20 concept and strongly advocated concerted regulatory reform) with a public conversion from self-confessed 'fiscal conservative' (his late 2007 campaign stance) into a self-consciously Keynesian 'social democrat' (his February 2009 essay).

Finally, our expectation on the likely support for the PM's framing attempts was not really met. On the back of what was widely - though not uncontroversially - perceived as a creditable performance in pre-empting an impending economic downturn, Rudd did enjoy a great spike in public support that lasted more than two years, but parts of the commentariat grew sceptical of his stance as economic saviour well before the Australian public did. Also, Gordon Brown at least in part defied the logic of this proposition by combining resolute international statesmanship with effective self-promotion during the immediate post-Lehman panic period. However, any 'rally around the flag effect' that may have occurred during this period quickly evaporated, and Brown, as predicted, suffered the same fate as Cowen: a public credibility gap as initial emergency measures failed to stem the impact of the GFC on their countries' 'real economies', reminding journalists and voters that the government of the day had actually been running the country during the time when all this had been allowed to happen.

More broadly, the findings of this study sit well with those scholars of the rhetorical presidency who stress 'the limits of the bully pulpit' (Edwards 2003). Our comparative 
data on the fate of prime-ministerial attempts to frame and reframe the global financial crisis of 2008-09 and its implications suggest that if the material realities leaders speak about are hard, immediate and widespread throughout society, their talk inevitably becomes soft by comparison. The brute economic facts that people experience in their everyday lives appear to trump the potential impact of leader discourse and 'spin'.

This should not be taken to mean that the whole idea of rhetoric (and its dramaturgy) as a policy and crisis management tool at the disposal of prime ministers ought to be dismissed as a non-starter. Even within the field of macro-economic management, Wood's (2007) robust findings on US presidential 'economic leadership by speech' suggest that there is considerable scope for government leaders to have a non-trivial impact on public (and market) sentiment when they talk the economy up (or down) in less extreme and more ambiguous circumstances than faced by the prime ministers in our sample. Also, there is enough evidence to suggest that in other types of crises, particular those that involve - or are widely framed as involving - public safety and national security, there is scope for astute rhetorical executive leadership to shape public cognitions, emotions and attitudes - and not just in presidential systems (Bostdorff 1994; Buzan et al. 1998; Domke et al. 2006; Boin et al. 2009; DeCastella et al. 2009).

Our study further shows that the public and political impact of leaders' issue framing efforts is mitigated by audience perceptions of their overall credibility (as, for example, evidenced by their track records) in the relevant policy domains. In the case of Brown and Cowen, both these factors conspired against their rhetorical leadership efforts. Both had been long-serving economic policymakers in now recession-affected countries. As a result, neither managed to escape the hard questions about their own responsibility for the economic mess they were trying as prime ministers to manage. Given the undeniable severity of the crisis, all that was left open to them was a pattern of 'staged retreat' (Hood et al. 2007): shifting from the rhetoric of blame avoidance (by externalizing causes and responsibilities) to that of blame management (e.g. Cowen's partial 'mea culpa'); and strongly advocating policy reform internationally, whilst playing down the urgency of domestic restructuring of financial regulation. To no avail of course: they and their parties experienced resolute electoral punishment at the earliest opportunity.

Finally, when taking their cues from the more voluminous and methodologically sophisticated work on US presidential rhetorical leadership, students of the emerging 'rhetorical premiership' should not forget that Westminster style prime ministers and US style presidents do not operate on a level playing field. Presidents do not face the adversarial parliamentary arena on the regular basis that prime ministers do. They can to a larger extent choose when, where and how they address the issues of the day. Institutionalized opposition and unrelenting accountability encounters such as question time deprive Westminster prime ministers of this opportunity. Though they too may face entrenched opposition, the political structure of presidential systems and the mythology of the office itself provide presidents with an enviable rhetorical and dramaturgical platform, allowing them to engage in highly consequential framing efforts whilst depicting themselves as being above the party-political fray. Franklin Roosevelt, for example, had no political opponent competing on an even rhetorical keel with him when framing the 1930s Depression during his fireside chats. Further comparative analysis of chief executives' crisis rhetoric across parliamentary (Westminster as well as consensual) and presidential systems would help us gain more systematic insight into the mediating effect of institutional structures on leadership styles and impacts (as 
argued more generally by, for example, Helms 2005)). In that respect, global crises such as the GFC, 9/11 and the 'war on terrorism', and the 'fallout' of nuclear calamities such as Chernobyl and Fukushima provide a rich empirical hunting ground waiting to be explored.

\section{REFERENCES}

Ben-Porath, E.N. 2007. 'Rhetoric of Atrocities: The Place of Horrific Human Rights Abuses in Presidential Persuasion Efforts', Presidential Studies Quarterly, 37, 2, 181.

Bligh, M.C. and G.D. Hess. 2007. 'The Power of Leading Subtley: Alan Greenspan, rhetorical leadership and monetary policy', The Leadership Quarterly, 18, 1, 87-104.

Boin, A., P. 't Hart, E. Stern and B. Sundelius. 2005. The Politics of Crisis Management: Public Leadership Under Pressure. Cambridge: Cambridge University Press.

Boin, A., A. McConnell and P. 't Hart (eds). 2008. Governing After Crises. Cambridge: Cambridge University Press.

Boin, A., A. McConnell and P. 't Hart. 2009. 'Crisis Exploitation: Political and Policy Impacts of Framing Contests', Journal of European Public Policy, 16, 1, 81-106.

Boin, A., A. McConnell, P. 't Hart and T. Preston. 2010. 'Leadership Style, Crisis Response and Blame Management: The Case of Hurricane Katrina', Public Administration, 88, 3, 706-23.

Bostdorff, D. 1994. The Presidency and the Rhetoric of Foreign Crisis. Columbia: University of South Carolina.

Buzan, B., O. Waever and J. de Wilde. 1998. Security: A New Framezork for Analysis. Boulder: Lynne Rienner

Cassidy, B. 2010. The Party Thieves: The Real Story of the 2010 Election. Melbourne: Melbourne University Press.

Curran, J. 2004. The Power of Speech: Australian Prime Ministers Defining the National Image. Melbourne: Melbourne University Press.

DeCastella, K., K. McGarty and L. Musgrove. 2009. ‘Fear Appeals in Political Rhetoric about Terrorism: An Analysis of Speeches by Australian Prime Minister Howard', Political Psychology, 30, 1, 1-26.

Domke, D., E.S. Graham, K. Coe, S.L. John and T. Coopman. 2006. 'Going Public as Political Strategy: The Bush Administration, an Echoing Press, and Passage of the Patriot Act', Political Communication, 23, 3, 291-312.

Edelman, M. 1977. Political Language. Chicago: University of Chicago Press.

Edwards, G.C. 2003. On Deaf Ears: The Limits of the Bully Pulpit. New Haven: Yale University Press.

Foley, M. 2001. The British Presidency. Manchester: Manchester University Press.

Gaffney, J. 2001. 'Imagined Relationships: Political Leadership in Contemporary Democracies', Parliamentary Affairs, 54, 2, $120-33$.

George, A.L. and A. Bennett. 2004. Case Studies and Theory Development in the Social Sciences. Cambridge: MIT Press.

Graber, D. 2004. 'Methodological Developments in Political Communication Research', in L.L. Kaid (ed.), Handbook of Political Communication Research. Mahwah: Erlbaum and Associates, pp. 45-68.

Griffin-Padgett, D.R. and D. Allison. 2010. 'Making a Case for Restorative Rhetoric: Mayor Rudolph \& Giuliani Mayor Ray Nagin's Response to Disaster', Communication Monographs, 77, 3, 376-92.

Hajer, M. 2009. Authoritative Governance. Oxford: Oxford University Press.

Hajer, M. and J. Uitermark. 2008. 'Performing Authority: Discursive Politics after the Assassination of Theo VanGogh', Public Administration, 86, 1, 5-19.

Hearit, K.M. 2006. Crisis Management by Apology: Corporate Response to Allegations of Wrongdoing. Mahwah: Lawrence Erlbaum Associates.

Heifetz, R. 1994. Leadership Without Easy Answers. Cambridge: Harvard Belknap.

Helms, L. 2005. Presidents, Prime Ministers and Chancellors. Basingstoke: Palgrave.

Helms, L. 2008. 'Governing in the Media Age: The Impact of Mass Media on Executive Leadership in Contemporary Democracies', Government and Opposition, 43, 1, 26-52.

Hermann, C.F. (ed.). 1972. International Crises: Insights from Behavioural Research. New York: Free Press.

Hood, C., W. Jennings, B. Hogwood and C. Beeston. 2007. Fighting Fires in Testing Times. London: CARR London School of Economics.

Hood, C., W. Jennings, R. Dixon, B. Hogwood and C. Beeston. 2009. ‘Testing Times: Exploring Staged Responses and the Impact of Blame Management Strategies in two Examination Fiasco Cases', European Journal of Political Research, 48, 6, 695-722.

Hurst, S. 2004. 'The Rhetorical Strategy of President George H.W. Bush during the Persian Gulf War', Political Studies, 52, 3 , 376-92.

Hutcheson, J., D. Domke, A. Billeaudeaux and P. Garland. 2004. ‘US National Identity, Political Elites, and a Patriotic Press Following September $11^{\prime}$, Political Communication, 21, 1, 27-50.

Hyde, M.J. 2005. 'The Rhetor as Hero and the Pursuit of Truth: The Case of 9/11', Rhetoric \& Public Affairs, 8, 1, 1.

Irish Independent. 2009. 'We can Handle the Truth Unwelcome 80s revival', Irish. Independent, 4 July. 
Kiewe, A. (ed.) 1994. The Modern Presidency and Crisis Rhetoric. Westport: Peaeger.

Kuypers, J.A. 1997. Presidential Crisis Rhetoric and the Press in the Post Cold War World. New York: Praeger.

Lukes, S. 1974. Power: A Radical View. London: Macmillan.

Lydon, P. 2010. 'Cowen Defends Economy Actions', Irish Times, 18 May, p. 18.

Masters, A. 2009. 'Republic of Ireland: From Celtic Tiger to Recession Victim', in P. 't Hart and K. Tindall (eds), Framing the Global Economic Downturn: Crisis Rhetoric and the Politics of Recession. Canberra: ANU E Press, pp. 127-55.

Nabers, D. 2009. 'Filling the Void of Meaning: Identity Construction in US Foreign Policy After September 11, 2001', Foreign Policy Analysis, 5, 2, 191-214.

Nacos, B.L. 1990. The Press, Presidents and Crises. New York: Columbia.

O'Malley, E. 2008. 'Ireland', European Journal of Political Research, 47, 7-8, 1012-18.

O'Malley, E. 2009. 'Political Data in 2008 Ireland', European Journal of Political Research, 48, 7-8, 986-91.

Poguntke, T. and P. Webb (eds). 2005. The Presidentialization of Politics: A Comparative Study of Modern Democracies. Oxford: Oxford University Press.

Rawnsley, A. 2010. The End of the Party. London: Viking.

REDC. 2010. 'Sunday Business Post - General Election Opinion Poll Report - 2007-2010'. REDC (http://www.redcresearch.ie/ results.html; accessed 10 December).

Reicher, S. and N. Hopkins. 1996. 'Self Category Construction in Political Rhetoric: An Analysis of Thatcher's and Kinnock's Speeches Concerning the British Miners' Strike (1984-85)', European Journal of Social Psychology, 26, 3, 353-71.

Riddell, P. 2008. 'Darling is No Saint, But His Sins are Exaggerated', The Times, 20 February, p. 24.

Rosenthal, U., M.T. Charles and P. ‘t Hart (eds). 1989. Coping with Crises. Springfield: Thomas.

Scheufele, D.A. 1999. 'Framing as a Theory of Media Effects', Journal of Communications, 49, 1, 103-22.

Seib, C. 2008. 'Sandler Presents Four-Point Plan to Revive Northern Rock', The Times, 19 February, p. 36.

Seymour-Ure, C. 2003. Prime Ministers and the Media. Oxford: Blackwell.

Simons, H.W. 2007. 'From Post-9/11 Melodrama to Quagmire in Iraq: A Rhetorical History', Rhetoric E Public Affairs, $10,2,183$.

Skowronek, S. 2008. Presidential Leadership in Political Time: Reprise and Reappraisal. Lawrence: University of Kansas Press.

't Hart, P. 1993. 'Symbols, Rituals and Power: The Lost Dimension of Crisis Management', Journal of Contingencies and Crisis Management, 1, 1, 36-51.

't Hart, P., K. Tindall and C. Brown. 2009. 'Crisis Leadership of the Bush Presidency: Advisory Capacity and Presidential Performance in the Acute Stages of the 9/11 and Katrina Crises', Presidential Studies Quarterly, 39, 3, 473.

Taylor, L. and D. Uren. 2010. Shitstorm: Inside Labor's Darkest Days. Carlton: Melbourne University Publishing.

Toye, R. 2010. 'The Rhetorical Premiership', Political Studies Association Conference.

Wagner-Pacifici, R. 1986. The Moro Morality Play: Terrorism and Social Drama. Chicago: University of Chicago Press.

Walter, J. and P. Strangio. 2007. No Prime Minister: Reclaiming Politics from Leaders. Sydney: University of New South Wales Press.

Whitford, A.B. and J. Yates. 2009. Presidential Rhetoric and the Public Agenda: Constructing the War on Drugs. Baltimore: John Hopkins University Press.

Winkler, C. 2007. 'Parallels in Pre-emptive War Rhetoric: Reagan on Libya; Bush 43 on Iraq', Rhetoric \& Public Affairs, $10,2,303$.

Wood, B.D. 2007. The Politics of Economic Leadership: The Causes and Consequences of Presidential Leadership. Princeton: Princeton University Press.

YouGov. 2008a. 'Daily Mirror Survey Results 15-17 October' (http://today.yougov.co.uk/sites/today.yougov.co.uk/files/YGArchives-pol-dMirror-vi-081021.pdf; accessed 13 December).

YouGov. 2008b. 'Economist Survey Results 18-20 February' (http://today.yougov.co.uk/sites/today.yougov.co.uk/files/YGArchives-pol-econ-NorthernRock-080222.pdf; accessed 13 December).

YouGov. 2009a. 'Daily Telegraph Survey Results 22-23 April' (http:/ / today.yougov.co.uk/sites/today.yougov.co.uk/files/YGArchives-pol-dTel-vi-090424.pdf; accessed 13 December).

YouGov. 2009b. 'Sky News Survey Results 29-30 September' (http:/ / today.yougov.co.uk/sites/today.yougov.co.uk/ files/YGArchives-pol-skynews-dp-090930.pdf; accessed 13 December).

YouGov. 2009c. 'Sunday Times Survey Results 12-13 November' (http:/ / today.yougov.co.uk/sites/today.yougov.co.uk/files/ YG-Archives-pol-stimes-vi-091116.pdf; accessed 13 December).

YouGov. 2010. 'The Sun Survey Results 10-11 March' (http://today.yougov.co.uk/sites/today.yougov.co.uk/files/YGArchives-Pol-Suntracker-100311.pdf; accessed 13 December).

Date received 14 December 2010. Date accepted 24 June 2011. 


\section{APPENDIX 1: THE CODED SPEECHES (AND ONE ESSAY)}

The reference list that follows only includes the speeches of the prime ministers that have been analysed in Section 5, or directly quoted elsewhere. Hence the non-sequential numbering. For a full list please contact the authors.

Brown, G. 2008a. 'Press Conference: Privatisation of Northern Rock - 18 February', London: Prime Minister's Office (http:/ / webarchive.nationalarchives.gov.uk/+/http:/ / www.number10.gov.uk/Page14588; accessed 28 October 2010).

Brown, G. 2008e. 'Press Conference with the Chancellor of the Exchequer - 8 October', London: Prime Minister's Office (http://webarchive.nationalarchives.gov.uk/200902100 05941/http:/www.number10.gov.uk/Page17114; accessed 2 April 2011).

Brown, G. 2008g. 'Speech on the Global Economic Crisis at the Reuters Building - 13 October', London: Prime Minister's Office (http:/ / webarchive.nationalarchives.gov.uk/ 20090505142052/http:/ /www.number10.gov.uk/Page18718; accessed 31 August 2010).

Brown, G. 2008h. 'Press Conference with the Chancellor of the Exchequer - 13 October', London: Prime Minister's Office (http:/ / webarchive.nationalarchives.gov.uk/200902100 05941/http:/www.number10.gov.uk/Page17163; accessed 31 August 2010).

Brown, G. 2009b. 'Speech on Global Economic Crisis - 26 January', London: Prime Minister's Office (http://webarchive.nationalarchives.gov.uk/20090210005941/http:/www. number10.gov.uk/Page18153; accessed 2 April 2011).

Brown, G. 2009g. 'PM Speech to European Parliament - 24 March', London: Prime Minister's Office (http://webarchive.nationalarchives.gov.uk/20090505142052/http:// www.number10.gov.uk/Page18718; accessed 31 August 2010).

Brown, G. 2009h. 'G20 Press Conference - 3 April', London: Prime Minister's Office (http:/ / webarchive.nationalarchives.gov.uk/20090505142052/http:/ /www.number10. gov.uk/Page18934; accessed 31 August 2010).

Brown, G. 2009m. 'Gordon Brown's Labour Conference Speech in Full - 29 September', The Guardian. London: Guardian News and Media Limited.

Brown, G. 2009r. 'Speech to G20 Finance Ministers - 7 November', London: Prime Minister's Office (http: / / webarchive.nationalarchives.gov.uk/20091111172404/http: / /www. number10.gov.uk/Page21248; accessed 31 August 2010).

Brown, G. 2010e. 'Speech on the Economy - 10 March', London: Prime Minister's Office (http:/ / webarchive.nationalarchives.gov.uk/20100511083528/http:/ /www.number10. gov.uk/news/speeches-and-transcripts/2010/03/speech-on-the-economy-22753; accessed 31 August 2010).

Brown, G. 2010j. The Change We Choose: Speeches 2007-2009. Mainstream Publishing.

Cowen, B. 2008a. 'Speech by the Taoiseach, Mr Brian Cowen, T.D., at the IBEC President's Dinner at the Mansion House, Dublin - 25 June', Dublin: Department of the Taoiseach (http://www.taoiseach.gov.ie/eng/Government_Press_Office/Taoiseach\%27s_ Speeches_2008/Speech_by_the_Taoiseach,_Mr_Brian_Cowen,_T_D_,at_the_IBEC_ President\%E2\%80\%99s_Dinner_at_the_Mansion_House,_Dublin_on_Wednesday,_25th_ June,_2008_at_7_30pm.html; accessed 14 April 2011).

Cowen, B. 2008c. 'Address by the Taoiseach, Mr. Brian Cowen T.D., to the CBI-IBEC Joint Business Council Dinner in Trinity College Dublin - 2 October', Dublin (http:/ /193.178.1 .117 /index.asp?locID=582\&docID=4031; accessed 28 March 2009).

Cowen, B. 2008d. 'Speech by An Taoiseach, Mr Brian Cowen, TD, Statement on Budget 2009, Dáil Éireann - 15 October', Dublin: Department of the Taoiseach (http:/ /www. taoiseach.gov.ie/eng/Government_Press_Office/Taoiseach\%27s_Speeches_2008/ 
Speech_by_An_Taoiseach,_Mr_Brian_Cowen,_TD,_Statement_on_Budget_2009,_D\% C3\%A1il_\%C3\%89ireann,_15th_October,_2008.html; accessed 14 April 2011).

Cowen, B. 2009c. 'Statement by the Taoiseach Mr. Brian Cowen, T.D. in Dáil Eireann: "Delivering sustainable economic renewal and securing our public finances" 28 January', Dublin (http:/ / www.taoiseach.gov.ie/index.asp?locID=605\&docID=4223; accessed 28 March 2009).

Cowen, B. 2009e. 'Taoiseach Announces Government Decision on the Implementation of the Framework for Stabilisation, Social Solidarity and Economic Renewal following Negotiations with the Social Partners - 3 February', Dublin (http://www.taoiseach.gov.ie/ index.asp?locID=605\&docID=4237; accessed 28 March 2009).

Cowen, B. 20091. 'Speech by the Taoiseach, Mr. Brian Cowen T.D. Debate on the Supplementary Budget in Dáil Éireann - 8 April', Dublin: Department of the Taoiseach (http://www.taoiseach.gov.ie/eng/Government_Press_Office/Taoiseach\%27s_ Speeches_2009/Speech_by_the_Taoiseach,_Mr_Brian_Cowen_T_D_Debate_on_the_ Supplementary_Budget_in_D\%C3\%A1il_\%C3\%89ireann_on_8th_April_2009.html; accessed 6 August 2010).

Cowen, B. 2009m. 'Speech by the Taoiseach, Mr. Brian Cowen T.D., in the debate on IMF and OECD Reports - 3July', Dublin: Department of the Taoiseach (http:/ / www.taoiseach. gov.ie/eng/Government_Press_Office/Taoiseach\%27s_Speeches_2009/Speech_by_the_ Taoiseach,_Mr_Brian_Cowen_T_D_,in_the_debate_on_IMF_and_OECD_Reports_on_ Friday,_3_July_2009_at_2_15pm.html; accessed 6 August 2010).

Cowen, B. 2009x. 'Statement on the Budget by the Taoiseach Mr. Brian Cowen T.D., Dáil Éireann - 10 December', Dublin: Department of the Taoiseach (http://www.taoiseach. gov.ie/eng/Government_Press_Office/Taoiseach\%27s_Speeches_2009/Statement_on_ the_Budget_by_the_Taoiseach_Mr_Brian_Cowen_T_D_,D\%C3\%A1il_\%C3\%89ireann, Thursday,_10_December_2009,_at_11_00_a_m_.html; accessed 6 August 2010).

Cowen, B. 2010f. 'Speech by An Taoiseach, Mr. Brian Cowen TD, North Dublin Chamber of Commerce, Dublin City University - "The Irish Banking Crisis - the Mistakes, the Responses and the Lessons" - $13 \mathrm{May}^{\prime}$, Dublin: Department of the Taoiseach (http://www.taoiseach.gov.ie/eng/Government_Press_Office/Taoiseach\%27s\%20 Speeches\%202010/Speech_by_An_Taoiseach_North_Dublin_Chamber_of_Commerce_ Dublin_City_University\%2013\%20May\%202010.html; accessed 6 August 2010).

Rudd, K. 2008a. 'Building Australia's Economic Future: Address to Lord Mayor's Business Breakfast, Perth - 21 January', Canberra: Australian Government (http://parlinfo. aph.gov.au/parlInfo/search/display/display.w3p;adv=yes;page=0;query=Id $\% 3 \mathrm{~A} \%$ 22media\%2Fpressrel\%2FF9HP6\%22;rec=0;resCount=63; accessed 12 April 2011).

Rudd, K. 2008e. 'Partner's in the Global Economy - Australia and the United States, Address to the US Chamber of Commerce, Washington, DC - 31 March', Canberra: Australian Government (http://www.pm.gov.au/media/Speech/2008/speech_0158.cfm; accessed 10 June 2009).

Rudd, K. 2008g. 'Address to the Centre for Independent Studies, Coolum - 3 August', Canberra: Australian Government (http:/ / parlinfo.aph.gov.au/parlInfo/search/display/ display.w3p;adv=yes;page=0;query=Id \%3A $\% 22$ media $\% 2 F$ pressrel $\% 2 F 8 P 6 R 6 \% 22 ; \mathrm{rec}=$ 0;resCount=63; accessed 12 April 2011).

Rudd, K. 2008r. 'Prime Minister's Address to the Nation, Parliament House, Canberra 14 October', Canberra: Australian Government (http:/ / www.pm.gov.au/media/Speech/ 2008/speech_0553.cfm; accessed 10 June 2009). 
Rudd, K. 2008s. 'Address To National Press Club, Canberra - 15 October', Canberra: Australian Government (http://parlinfo.aph.gov.au/parlInfo/search/display/ display.w3p;adv=yes;page =0; query $=\mathrm{Id} \% 3 \mathrm{~A} \% 22$ media $\% 2 F p r e s s r e l \% 2 F 96 U R 6 \% 22 ; \mathrm{rec}=$ 0;resCount=63; accessed 12 April 2011).

Rudd, K. 2008u. 'Address to the Small Business Summit, Brisbane - 24 October', Canberra: Australian Government (http://parlinfo.aph.gov.au/parlInfo/search/display/ display.w3p;adv=yes;page =0; query $=\mathrm{Id} \% 3 \mathrm{~A} \% 22$ media $\% 2 \mathrm{Fpressrel} \% 2 \mathrm{~F} 9 \mathrm{WXR} 6 \% 22$; rec=0;resCount=63; accessed 12 April 2011).

Rudd, K. 2008v. 'Securing Australia's Economic Future: The Essence of Confidence: Speech to Australia Unlimited Roundtable, Melbourne - 28 October', Canberra: Australian Government (http:/ / parlinfo.aph.gov.au/parlInfo/search/display/display.w3p; $\mathrm{adv}=$ yes;page $=0$; query=Id $\% 3 \mathrm{~A} \% 22$ media $\% 2$ Fpressrel $\% 2 \mathrm{FYY} 2 \mathrm{~S} 6 \% 22 ; \mathrm{rec}=0$;res Count=63; accessed 12 April 2011).

Rudd, K. 2008z. 'Ministerial Statement in the House of Representatives, Parliament House, Canberra - 26 November', Canberra: Australian Government (http:/ /www.pm. gov.au/media/Speech/2008/speech_0635.cfm; accessed 10 June 2009).

Rudd, K. 2009a. 'The Global Financial Crisis', The Monthly, 42.

Rudd, K. 2009d. 'Transcript of Doorstop: Gladstone, Qld: 4 March 2009: Terrorist Attack against Sri Lankan Cricket Team; National Account Figures, Global Economic Recession; Nation Building and Job Plan; Support for Apprentices; Efficiency Dividend', Canberra: Australian Government (http://parlinfo.aph.gov.au/parlInfo/search/display/display. w3p;adv=yes;page =0; query $=\mathrm{Id} \% 3 \mathrm{~A} \% 22$ media $\% 2 F$ pressrel $\% 2 \mathrm{FU} 3 \mathrm{YS} 6 \% 22 ; \mathrm{rec}=0$; resCount=100; accessed 12 April 2011).

Rudd, K. 2009j. 'We Are All In This Together: A Jobs and Training Compact with Australia: Speech at the Brotherhood of St Lawrence Jobs Forum, Melbourne - 5 April', Canberra: Australian Government (http://parlinfo.aph.gov.au/parlInfo/search/display/ display.w3p;query=Id\%3A\%22media\%2Fpressrel\%2F3T8T6\%22; accessed 23 August 2010).

Rudd, K. 2009s. 'Speech to the ACTU Congress 2009, Brisbane - 3 June', Canberra: Australian Government (http:/ / parlinfo.aph.gov.au/parlInfo/search/display/display.w3p; query $=\mathrm{Id} \% 3 \mathrm{~A} \% 22 \mathrm{media} \% 2 \mathrm{Fpressrel} \% 2 \mathrm{FXGAU6 \% 22;} \mathrm{accessed} 23$ August 2010).

Rudd, K. 2009z. 'A Strategy for a Sustainable Economic Recovery - The Role of the G20: Speech, Berlin - 7 July', Canberra: Australian Government (http://parlinfo.aph.gov. $\mathrm{au} /$ parlInfo/search/display / display.w3p;query=Id $\% 3 \mathrm{~A} \% 22$ media\%2Fpressrel\%2FY T3U6\%22; accessed 23 August 2010).

Rudd, K. 2010c. 'Building Australia's Future: Building a Skilled Workforce for the Jobs of the Future: Speech to Australia Day Reception, Perth - 21 January', Canberra: Australian Government (http://parlinfo.aph.gov.au/parlInfo/search/display/display.w3p; $\mathrm{adv}=$ yes;page $=0 ;$ query $=\mathrm{Id} \% 3 \mathrm{~A} \% 22$ media $\% 2$ Fpressrel $\% 2 F G G Q V 6 \% 22 ; \mathrm{rec}=0$; resCount=100; accessed 12 April 2011).

Rudd, K. 2010e. 'Address to Griffith Australia Day Awards, Brisbane - 23 January', Canberra: Australian Government (http://parlinfo.aph.gov.au/parlInfo/search/display/ display.w3p;adv=yes;page=0; query=Id\%3A\%22media $\% 2 F$ pressrel $\% 2 F Y 9 Q V 6 \% 22$; rec=0;resCount=100; accessed 12 April 2011). 